\title{
Al-hijamah (wet cupping therapy of prophetic medicine) significantly and safely reduces iron overload and oxidative stress in thalassemic children: a novel pilot study
}

This article was published in the following Dove Press journal:

Journal of Blood Medicine

\begin{abstract}
Mohamed El-Shanshory, ${ }^{1,2}$ Nahed M Hablas, ${ }^{2}$ Yasmin Shebl, ${ }^{2}$ Ahmed R Fakhreldin, ${ }^{3}$ Mohamed Attia, ${ }^{4}$ Hamdi H Almaramhy, ${ }^{5}$ Hussam Baghdadi, ${ }^{6}$ Mongi Ayat, ${ }^{1,6}$ Amal Albeihany, ${ }^{7}$ Amr El-Dardear, ${ }^{1,8,9}$ Hoda Ali Ibrahim, ${ }^{10}$ Hany Salah Mahmoud," Manal Mohamed Helmy Nabo, 12,13 Salah Mohamed El Sayed ${ }^{1,6,14}$
\end{abstract}

'Prophetic Medicine Course and Research, Taibah College of Medicine, Medina, Saudi Arabia; ${ }^{2}$ Department of Pediatrics, Tanta University Faculty of Medicine, Tanta Gharbia, Egypt; ${ }^{3}$ Department of Pediatrics, Aswan Faculty of Medicine, Aswan University, Aswan, Egypt; ${ }^{4}$ Department of Clinical Pathology, Tanta Faculty of Medicine, Tanta University, Tanta, Egypt; ${ }^{5}$ Department of Surgery, Taibah Faculty of Medicine, Taibah University, Medina, Saudi Arabia; ${ }^{6}$ Department of Clinical Biochemistry and Molecular Medicine, Taibah Faculty of Medicine, Taibah University, Medina, Saudi Arabia; ${ }^{7}$ Department of Hematology, King Fahd Hospital, Ministry of Health, Medina, Saud Arabia; ${ }^{8}$ Department of Pediatrics, Faculty of Medicine, Taibah University, Medina, Saudi Arabia; 'Department of Pediatrics, Faculty of Medicine, Cairo University, Cairo, Egypt; ${ }^{10}$ Department of Biochemistry, Tanta Faculty of Medicine, Tanta University, Tanta, Egypt; "'Scientific Center for Experimental and Research Studies, Cairo, Egypt; ${ }^{12}$ Division of Pediatric Intensive Care Unit, King Fahad Hospital, Ministry of Health, Medina, Saudi Arabia; ${ }^{13}$ Division of Pediatric Cardiology, Pediatrics Department, Sohag Teaching Hospital, Ministry of Health, Sohag, Egypt; ${ }^{14}$ Department of Medical Biochemistry, Sohag Faculty of Medicine, Sohag University, Sohag, Egypt
Background: Thalassemia is a major health problem due to iron overload, iron deposition and oxidative stress-induced tissue damage. Here, we introduce Al-hijamah (a minor surgical excretory procedure) as a novel percutaneous iron excretion therapy. Al-hijamah is a wet cupping therapy of prophetic medicine, and prophet Muhammad, peace be upon him, strongly recommended Al-hijamah, saying: "The best of your treatment is Al-hijamah".

Aim of the study: Our study aimed at investigating the safety, iron chelation, pharmacological potentiation and oxidant clearance effects exerted by Al-hijamah to thalassemic children.

Patients and methods: Ethical committee's approval and patients' written agreement consents were obtained. We treated 20 thalassemic children ( 15 males and five females aged $9.07 \pm 4.26$ years) with iron chelation therapy (ICT) plus Al-hijamah (using sterile disposable sets and in a complete aseptic environment) vs a control group treated with ICT only. This clinical trial was registered in the ClinicalTrial.gov registry under the name "Study of the Therapeutic Benefits of Al-hijamah in Children with Beta Thalassemia Major" (identifier no NCT 02761395) on 30 January 2016.

Results: Al-hijamah was quite simple, safe, effective, tolerable (with no side effects) and time-saving procedure (30-60 minutes). A single session of Al-hijamah significantly reduced iron overload $(P<0.001)$ in all thalassemic children. Al-hijamah significantly decreased serum ferritin by $25.22 \%$ (from $3,778.350 \pm 551.633 \mathrm{ng} / \mathrm{mL}$ to $2,825.300 \pm 558.94 \mathrm{ng} / \mathrm{mL}$ ), significantly decreased oxidative stress by $68.69 \%(P<0.05$; serum malondialdehyde dropped from $42.155 \pm 12.42$ to $13.195 \pm 0.68 \mathrm{nmol} / \mathrm{L})$, exerted pharmacological potentiation to ICT and significantly increased total antioxidant capacity $(P<0.001)$ by $260.95 \%$ (from $13.195 \pm 0.68 \mathrm{nmol} / \mathrm{L}$ to $42.86 \pm 12.40 \mathrm{nmol} / \mathrm{L}$ through excreting reactive oxygen species). Moreover, therapeutic indices for evaluating Al-hijamah were promising.

Conclusion: Al-hijamah is a novel, safe, effective percutaneous iron excretion therapy through percutaneous iron excretion with minimal blood loss in agreement with the evidence-based Taibah mechanism. Al-hijamah is an effective outpatient hematological procedure that is safer than many pediatric procedures such as catheterization, hemofiltration and dialysis. Increasing the number of cups during Al-hijamah session or the number of sessions reduces iron overload more strongly. Medical practice of Al-hijamah is strongly recommended in hospitals.

Keywords: thalassemia, Al-hijamah, iron chelation therapy, oxidative stress, clearance, Alhijamah indices

\section{Introduction}

Thalassemia is still a big health problem especially in developing countries characterized by iron overload, oxidative stress-induced tissue damage, hypersplenism and transfusion
Department of Clinical Biochemistry and Molecular Medicine, Taibah Faculty of Medicine, Taibah University, Medina, Saudi Arabia

Tel +96650355 I588

Email salahfazara@yahoo.com 
dependence. Oxidative stress plays a major role in the pathophysiology of thalassemia. Iron overload in thalassemia may cause serious tissue damaging effects due to the generation of oxygen radicals that exceed the antioxidant capacity of body cells. ${ }^{1}$ Iron is a major oxidant in vivo ${ }^{2}$ where iron-induced generation of reactive oxygen species (ROS) is responsible for the tissue-damaging effects, ${ }^{3}$ depletion of endogenous antioxidants, lipid peroxidative damage ${ }^{4}$ and formation of the major atherogenic factor (oxidized low density lipoprotein) causing atherosclerosis. Lipoperoxides in liver and spleen homogenates are high in conditions of iron overload. Noteworthy, oxidative stress in thalassemia patients was reported to impair platelet functions with high plasma oxidative stress indicators, eg, thiobarbituric acid reactive substance (TBAR) levels, that improved with the use of antioxidants., ${ }^{4,5}$

Cupping therapy is the term given to therapies using sucking cups that are applied to skin areas for different therapeutic purposes. Cupping therapy is a simple, safe, tolerable, effective, economic and time-saving treatment. Traditional wet cupping therapy is a two-step technique that involves scarification of the skin superficially followed by cupping, ie, double $\mathrm{S}$ technique. In a German study, traditional wet cupping therapy proved effective for treating carpal tunnel syndrome. ${ }^{6}$ Al-hijamah (wet cupping therapy of prophetic medicine) is a three-step technique (suction, scarification and suction technique, ie, triple $\mathrm{S}$ technique). Al-hijamah is an effective excretory treatment that clears blood and interstitial spaces from causative pathological substances according to the evidence-based Taibah mechanism. ${ }^{7,8}$

Al-hijamah is Arabic wet cupping therapy practiced in many Arabic countries. It is among the heritage of Arabic medicine and is also termed wet cupping therapy of prophetic medicine $^{7,8}$ that is therapeutically more effective than traditional Chinese wet cupping therapy. ${ }^{7,8}$ In our previous publications, we strongly recommended Al-hijamah for routine medical practice in hospitals for treating a large number of diseases differing in etiology and pathogenesis. We strongly suggested Al-hijamah for treating thalassemia. Al-hijamah significantly decreased serum ferritin in healthy subjects and is promising for treating thalassemia. Al-hijamah is an excretory treatment that clears blood significantly of noxious substances. ${ }^{9,10}$ Thalassemia may be a good choice for being treated using Al-hijamah to clear thalassemic blood of excess iron and ferritin (through percutaneous iron excretion) as we suggested in previous publications. ${ }^{9,10}$ Here, we introduce Al-hijamah as a novel percutaneous iron excretion therapy (PIET) as we will discuss here. Interestingly, Al-hijamah proved effective in treating autoimmune disease ${ }^{11}$ and migraine headache, ${ }^{12}$ although they differ from each other in etiology and pathogenesis.
Al-hijamah is generally indicated to clear blood and interstitial fluids from any abnormally increased causative pathological substances, eg, high serum ferritin, according to the evidence-based Taibah mechanism (Taibah theory) where wet cupping therapy utilizes an excretory physiological principle (pressure-dependent excretion) that resembles excretion through renal glomerular filtration. ${ }^{7,8}$ During A1hijamah, skin acts as a super kidney causing general direct excretion of causative pathological substances in a physiological manner. Al-hijamah is a general clearance treatment that significantly and simultaneously clears tissues, intercellular fluids and blood of different pathological substances. Al-hijamah exerts a percutaneous pressure-dependent clearance of both the blood and interstitial fluids (using the fenestrated skin capillaries that resemble renal glomerular capillaries in structure) to clear the skin blood circulation (a part of the systemic circulation) from the excess pathological substances. ${ }^{7,8}$ Although the clearance is partial in many conditions, it is quite significant, therapeutically beneficial and can be increased via increasing the number of sucking cups and Al-hijamah sessions. Based on Taibah mechanism (Taibah theory), Al-hijamah is suitable for treating many conditions of diseases differing from each other in etiology and pathogenesis, ${ }^{7,8}$ eg, autoimmune diseases, ${ }^{11}$ where Alhijamah will clear serum and interstitial fluids from related noxious substances such as ferritin and ROS in thalassemia and autoantibodies and inflammatory mediators in autoimmune diseases. ${ }^{11}$

In this study, we investigated the outcome of treating thalassemic children using Al-hijamah.

\section{Patients and methods}

\section{Patients}

Approval from the ethical committee of Tanta University Faculty of Medicine (Tanta, Egypt) and patients' written agreement consents were obtained. We confirm that the written informed consent was obtained from the parents or legal guardian of the treated children. Our study was performed on $40 \beta$-thalassemia major children (aged 9.07 \pm 4.26 years). They were divided into control group (continued on iron chelation therapy [ICT])) and treatment group (15 males and five females who received both Al-hijamah and ICT). All children received regular ICT. Children in both groups were matched in age, sex and duration of illness.

Inclusion criteria for this study were as follows:

1. definite diagnosis of $\beta$-thalassemia major;

2. patient's agreement to be enrolled in the study and

3. receiving $\mathrm{ICT}$. 
Exclusion criteria for this study were as follows:

1. presence of associated hematological or non-hematological disorders, and

2. presence of any complications of thalassemia, eg, hypersplenism, viral hepatitis, gall stones, stroke and severe anemia.

Same ICT was confirmed as a regular treatment for all the thalassemic children (daily deferasirox 20-30 mg/kg/day once before meal). Thalassemic children having persistently elevated serum ferritin levels $>3,000 \mathrm{ng} / \mathrm{mL}$ received a more vigorous treatment in the form of a combination of deferasirox and desferrioxamine $(20-40 \mathrm{mg} / \mathrm{kg}$ for 8-12 hours using subcutaneous infusion or continuous intravenous infusion for 8-10 hours/day for 10 days per month).

Ethics approval to perform this study was obtained from the Tanta Faculty of Medicine Ethical Committee, Tanta University, Gharbeya Governorate, Egypt, on 24 October 2014. Trial registration was done in www.ClinicalTrials.gov under the name "Study of the Therapeutic Benefits of Al-hijamah in Children with Beta Thalassemia Major" (NCT 02761395). This clinical trial was registered on 30 January 2016.

\section{Transfusion regimen and ICT for thalassemic children}

Transfusion regimen was done every $2-4$ weeks. The recommended treatment for thalassemia major involves lifelong regular blood transfusions (usually administered every 2-5 weeks) to maintain the pretransfusion hemoglobin level $>9-10.5 \mathrm{~g} / \mathrm{dL}$. The volume per transfusion is usually $10-15 \mathrm{~mL} / \mathrm{kg}$, administered over 3-4 hours. This transfusion regimen promotes normal growth, allows normal physical activities, adequately suppresses bone marrow activity in most patients and minimizes transfusional iron accumulation. ${ }^{13,14}$

\section{Performing Al-hijamah (a novel hematological procedure for treating thalassemia)}

Al-hijamah was done for once to allow evaluation of the therapeutic benefits vs rare possible side effects. Al-hijamah set (SpaCare Cupping, Beijing, China) includes 12 variable-sized sterile new disposable plastic cups and a hand-held pump for sucking the skin using cups. Skin scarifications were done using sterile single-use carbon steel disposable scalpel (sterilized by gamma radiation) Stainless Steel Blade No 11 (Integra ${ }^{\mathrm{TM}}$ Miltex ${ }^{\circledR}$, New York, NY, USA). All children were kept on the regular schedule of ICT. Al-hijamah was done in complete aseptic atmosphere using new sterile disposable sets (Figure 1A)
With the patients sitting comfortably, steps of Al-hijamah (triple $\mathrm{S}$ technique) were as follows:

1. sterilization of the skin of the upper back and upper chest (Figure 1B)

2. suction (for $\sim 5$ minutes) through applying sucking cups at moderate suction pressure to create skin upliftings at sites of cups' application (Figure 1C and D)

3. scarification of the skin - scarification is superficial (the Arabic term is shartat mihjam) and is done immediately at sites of cups at the skin upliftings (Figure 2A-D). Scarifications should be productive (Figure 2C-D)

4. suction through applying sucking cups (for 3-5 minutes) is done immediately after skin scarification and is repeated two or three times to remove the bloody excretion (Figure 3A-C)

5. sterilization of the skin after Al-hijamah (Figure 3D).

Same five steps were done on the upper part of the sternum (Figure 3E and F). There was no need to give antibiotics at the end of the procedure. Pediatric hematologists attended at the patients' bedside during Al-hijamah session and were ready with facilities for treating any expected rare side effects, eg, fainting, that might occur during Al-hijamah. Patients were allowed to discontinue at any time during the procedure. No problems occurred during performing this therapeutic hematological procedure, and all patients completed the study.

Shartat mihjam is the Arabic term given to the superficial skin scarifications (Figure 2A-D). Skin scarifications of Alhijamah reflect the hand skills that differentiate one skillful practitioner from another. Skin scarifications should be multiple, longitudinal ( $\sim 1-2 \mathrm{~mm}$ in length, ie, not pinpoint pricks), in parallel rows, equally distributed and productive. Malpractice of Al-hijamah is caused by any violation of these criteria and may carry side effects. Practitioner's skill is required to do superficial skin scarifications (the Arabic term is shartat mihjam) properly for better blood clearance.

Being a hand skill that is practiced for the first time as a novel treatment for thalassemia, variations in gaining excretory and clearance benefits may occur. Productive superficial skin scarifications (the Arabic term is shartat mihjam) (Figure $2 \mathrm{C}$ and $\mathrm{D}$ ) is the golden standard for successful Al-hijamahinduced blood and tissue clearance, while both nonproductive and partially productive superficial skin scarifications (the Arabic term is shartat mihjam) do not do well. Deep skin scarifications are a malpractice and may cause unnecessary profuse bleeding due to faulty damaging the fenestrated dermal skin capillaries that act as a filter (according to the evidence-based Taibah mechanism and theory). ${ }^{7-10}$ Thera- 
A

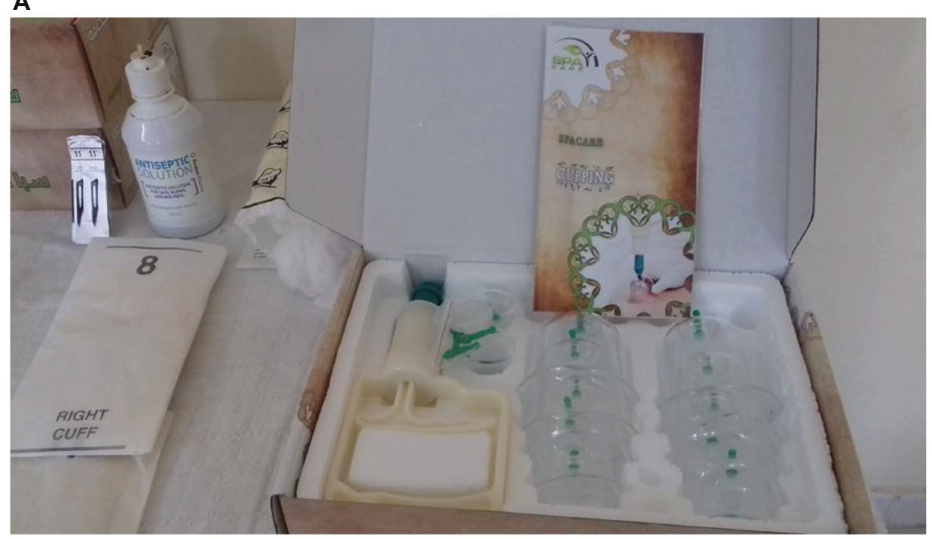

B

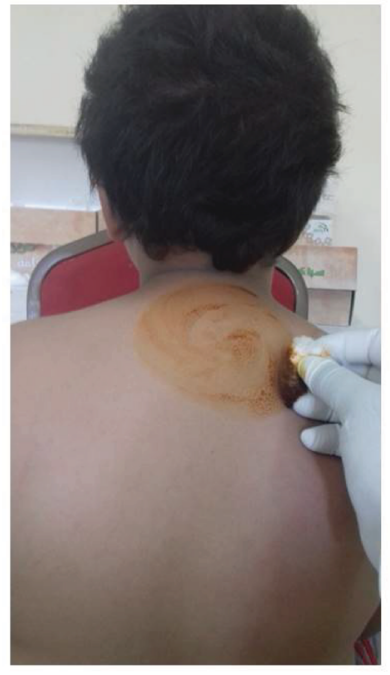

D

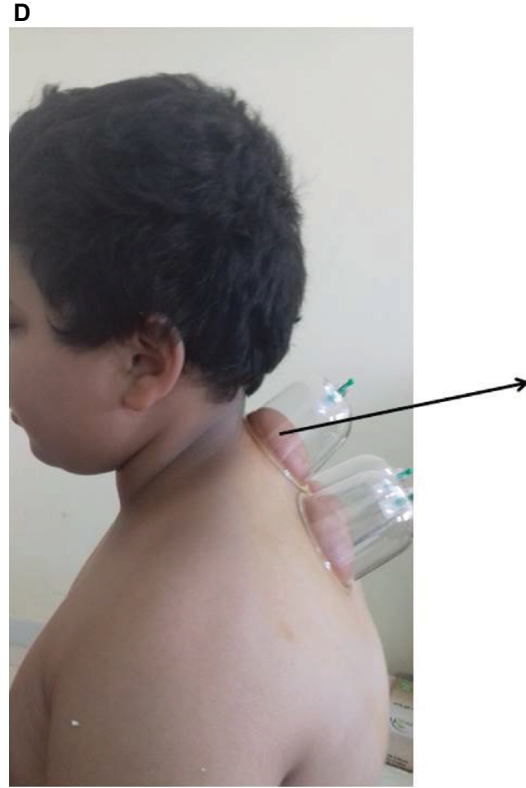

C

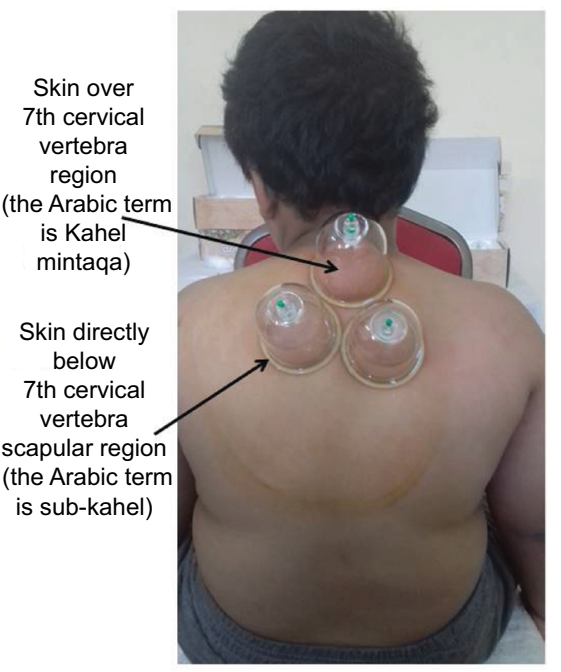

Inside sucking cups,

skin uplifitings are

created beneath

in which exist collected

fluids (containing

causative pathological

substances, eg,

ferritin) that cannot

be excreted due to

the presence of intact

skin barrier

Figure I Preparation for performing Al-hijamah (wet cupping therapy of prophetic medicine).

Notes: (A) The sterile disposable new set of cups includes 12 cups of variable sizes and a hand-held pump. Large-sized cups are put at the upper back and upper chest. Antiseptic solution, eg, povidone iodine; sterile disposable sharp scalpels (size no II); sterile cotton; sterile new gloves and clean sterile atmosphere at hospitals are the prerequisites for performing Al-hijamah. (B) Sterilization using povidone iodine cleaning from inside outward to clean all the areas in the upper back for application of cups. (C) First suction step of Al-hijamah. Using sucking cups where the negative pressure is created through manual suction and skin upliftings are created inside sucking cups. Sucking cups are put at the upper back region (at skin over 7th cervical vertebra and skin directly below 7th cervical vertebra scapular regions). (D) Inside sucking cups, skin upliftings are created beneath which exist collected fluids (local interstitial fluids+filtered fluids from skin capillaries) that cannot be excreted due to the presence of intact keratinized outermost layer of epithelium (skin barrier). The collected excreted fluids contain both disease-related substances and disease-causing substances (causative pathological substances, eg, ferritin, from serum and tissue deposits in iron overload conditions and oxidative stress indicators, eg, malondialdehyde). 

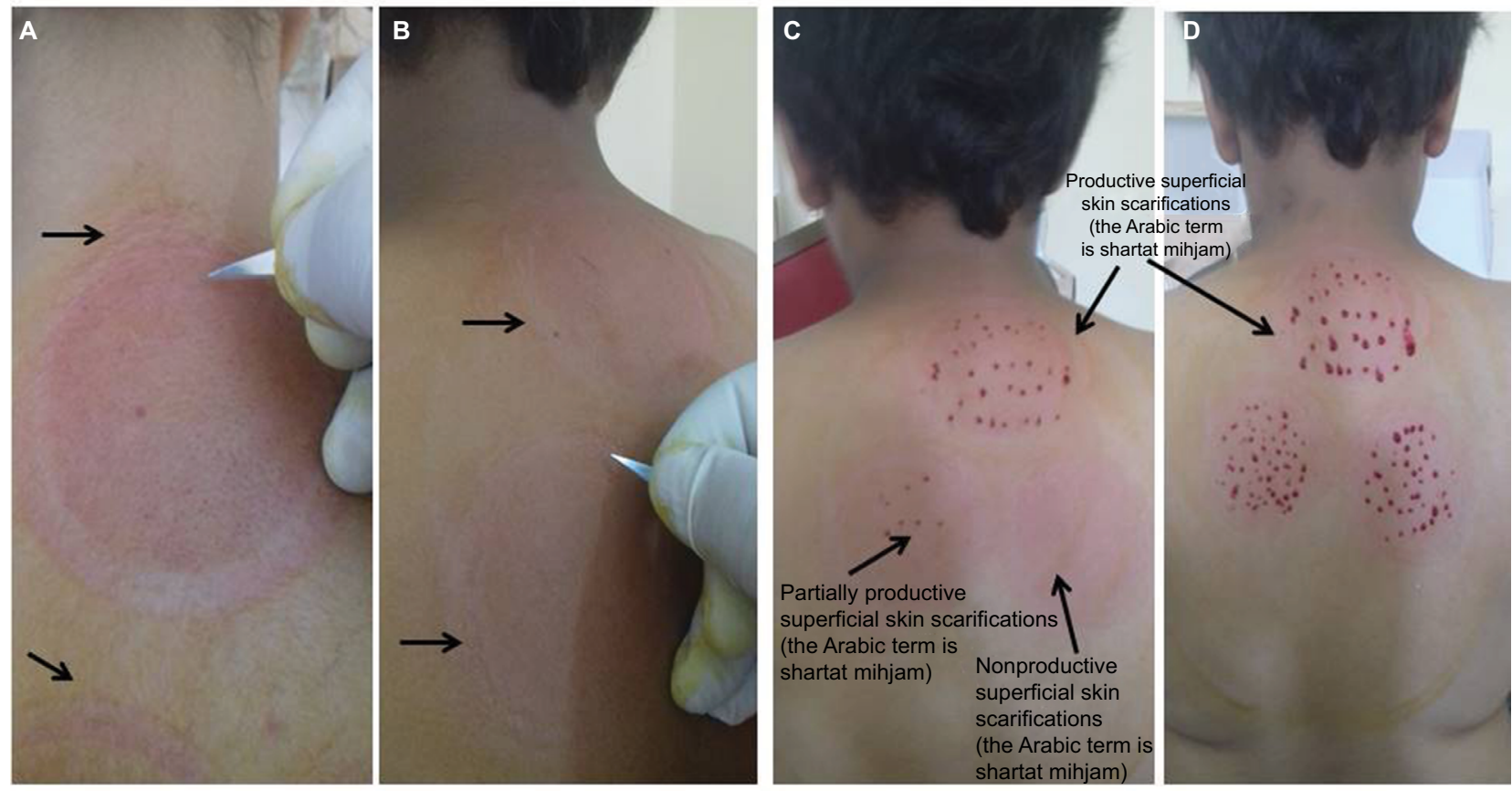

Figure 2 Skin scarification step (superficial skin scarifications; the Arabic term is shartat mihjam) to open the intact skin barrier and enhance dermatological excretion. Notes: (A) Line of demarcation of the skin upliftings after removal of the cups of the first sucking step. (B) Handling the scalpel for skin scarification is similar to holding a pen. Scarifications should be superficial scratches. The golden standard when making scarifications is to touch but never cut the skin. (C) Superficial skin scarifications (the Arabic term is shartat mihjam) should be productive to get optimal excretory function and therapeutic benefits after Al-hijamah (wet cupping therapy of prophetic medicine). Superficial skin scarifications (the Arabic term is shartat mihjam) should not be nonproductive or partially productive. (D) Productive shartat mihjam is the Arabic term given to the superficial skin scarifications $(\sim 0.1 \mathrm{~mm}$ in depth that preserves the structure of the superficial fenestrated dermal capillaries) that are confined to the skin dome (skin uplifting created after the first suction step). Skin scarifications of Al-hijamah denote the hand skills that differentiate one skillful practitioner from another. Skin scarifications should be multiple, longitudinal ( I-2 mm in length, ie, not pinpoint pricks), in parallel rows, equally distributed and productive.

peutic benefits of Al-hijamah are related to the amount of excreted causative pathological substances, eg, ferritin and malondialdehyde, but not the amount of letted blood.

\section{Biochemical evaluation}

Oxidative damage to cellular lipids was was quantified by measurement of serum malondialdehyde level using commercial kits (Biodiagnostic, Giza, Egypt). Total antioxidant capacity (TAC) level was assayed by commercial kits. Serum ferritin was measured in patients' serum in the Central Laboratory of the Hematology and Clinical Pathology Department of Tanta University Hospital, Tanta, Egypt.

\section{Indices for evaluating therapeutic effects of Al-hijamah ${ }^{8,9}$}

All the measurements were done within 1 month duration after the single session of Al-hijamah. Indices of Al-hijamah were estimated as previously described. ${ }^{8,9}$

To estimate the magnitude of therapeutic benefits gained after Al-hijamah, therapeutic indices of Al-hijamah were done for patients in the treatment group who underwent Al-hijamah but not for patients in the control group as they did not undergo Al-hijamah. Al-hijamah-induced therapeutic benefits were quantitated using the following therapeutic indices:

1. Excretion index (excretion value [EV])was estimated. EV was estimated after Al-hijamah to measure the degree of Al-hijamah-induced decrease in serum ferritin and malondialdehyde. EV measures the quantity of noxious substances excreted after the end of the session of Al-hijamah in quantity units/volume units. EV can be calculated by determining the difference in the levels of noxious substances before and after Al-hijamah (in quantity units/volume units).

$\mathrm{EV}=$ (initial concentration of any substance in serum before Al-hijamah in concentration unit/blood volume unit)-(concentration of the same substance in serum after Al-hijamah in concentration unit/blood volume unit).

2. Purification index (PI) was estimated after Al-hijamah to measure the degree of Al-hijamah-induced decrease in serum ferritin and malondialdehyde.

PI measures the percentage purification of plasma from any causative pathological substances estimated at different time points after Al-hijamah. Plasma clearance index or PI is the percentage purification of plasma from any noxious substance or component. PI can be calculated by 
A

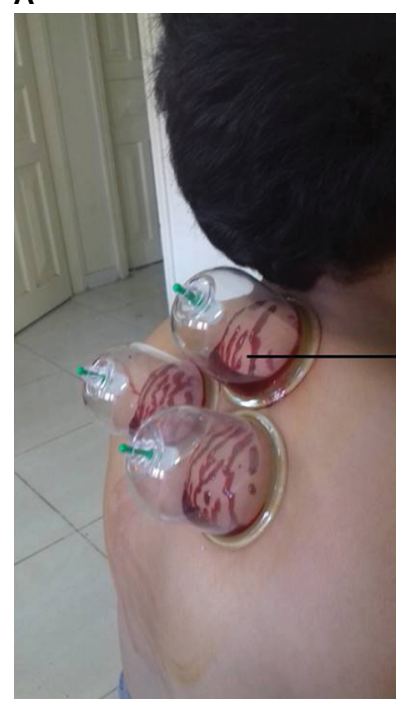

D

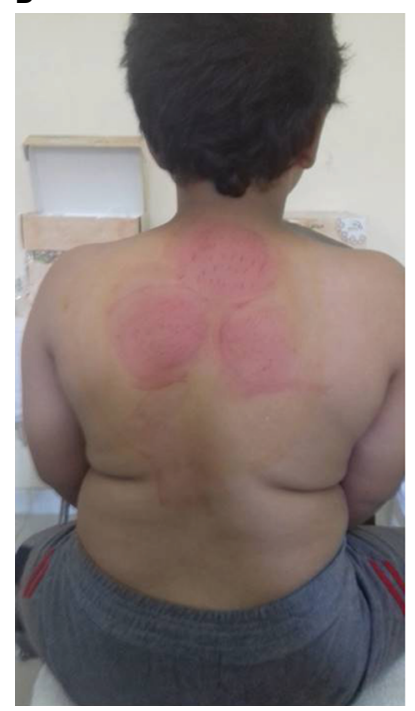

Streaks of bloody excretion coming out through the $\rightarrow$ superficial skin scarifications (the Arabic term is shartat mihjam) until clotting occurs

E

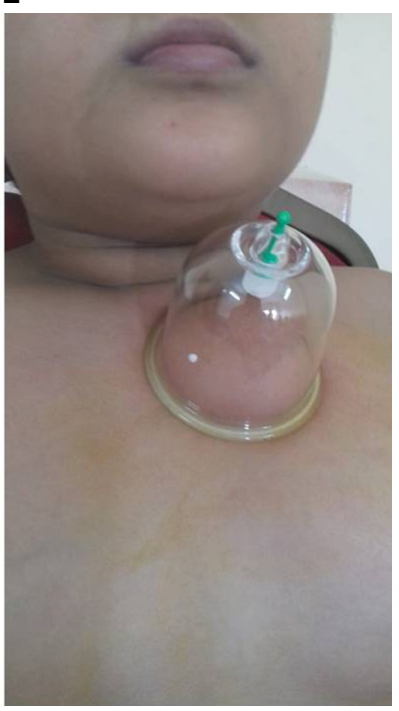

B

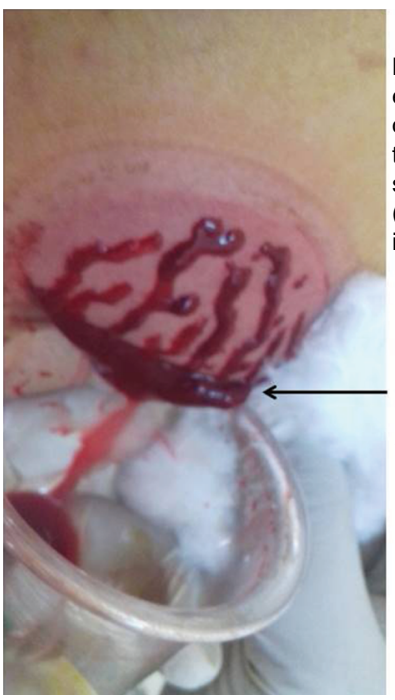

F
C

Bloody excretion occurs through the superficial skin scarifications (the Arabic term is shartat mihjam)

Excretory skin function is enhanced during Al-hijamah (wet cupping therapy of prophetic medicine) till blood clotting terminates the excretion

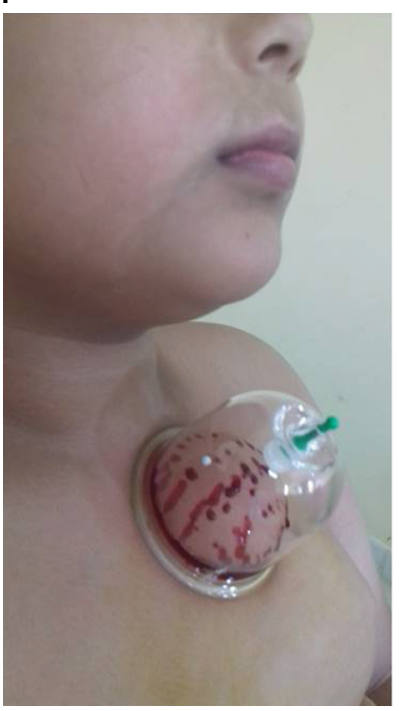

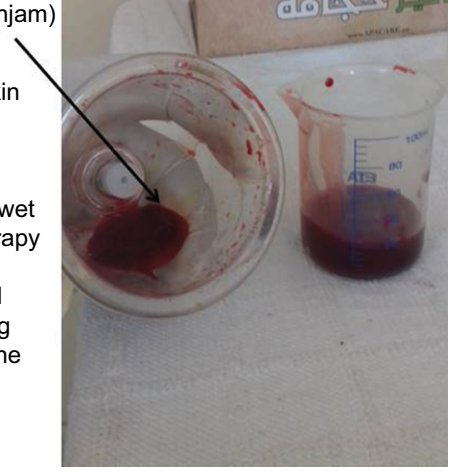

G

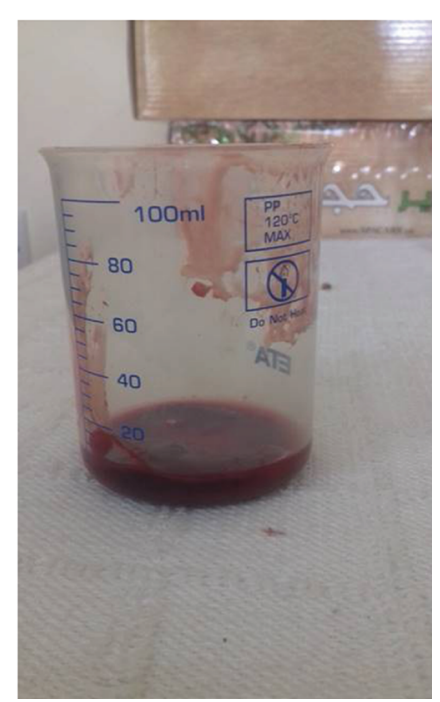

Figure 3 Second suction step is done immediately after skin scarifications.

Notes: (A and B) Bloody excretion starts to come out through the skin scratches (superficial skin scarifications; the Arabic term is shartat mihjam) in a rapid rate in the beginning and then slows down until stopping due to formation of blood clots. Bloody excretion persists until clotting occurs. (C) Bloody excretion is not profuse or causes hemorrhage if superficial skin scarifications (the Arabic term is shartat mihjam) are superficial and not deep. Causative pathological substances, eg, ferritin, iron, cholesterol, ROS and others, are directly excreted in the bloody excretion causing partial clearance of patient's blood and interstitial spaces. (D) Blood clots are cleaned with sterile cotton, and sucking cups are evacuated. Suction is repeated for two to three times until no material comes out. Skin upliftings and scarifications are sterilized with povidone iodine. They disappear within many hours to few days. There is no need for antibiotics. (E) The same first suction step is applied to the upper part of the chest. (F) The same superficial skin scarification step is applied to the upper part of the chest. (G) Bloody excretion occurring through Al-hijamah is minimal (average 50 cc that does not aggravate the anemic status of thalassemia)

Abbreviation: ROS, reactive oxygen species.

estimating the difference between the concentration of a noxious substance before and after Al-hijamah divided by its initial plasma concentration level. PI can be calculated from the following formula:

$\mathrm{PI}=100 \times([$ initial concentration of any substance in serum before Al-hijamah-concentration of the same substance in serum after Al-hijamah]/initial concentration of same substance in serum before Al-hijamah).

3. Pharmacological potentiation index (PPI) measures the degree of pharmacological potentiation gained when conventional pharmacological treatments are administered concomitantly with practicing Al-hijamah. It also compares the therapeutic benefits added by concomitant pharmacological treatments plus Al-hijamah vs using conventional pharmacological treatment as a sole treatment. PPI was estimated after Al-hijamah to measure the degree of Al-hijamah-induced increase in TAC.

PPI $=(100 \times$ therapeutic effects of [Al-hijamah+conventional pharmacological treatments]/[therapeutic effects of conventional pharmacological treatments only]). 


\section{Statistical analyses}

Data were collected, coded and analyzed using SPSS software for Windows version 21 (Chicago, IL, USA). Continuous variables were analyzed as mean values \pm standard error of mean. Paired $t$-test was used to compare results before and after treatment (paired data). Independent $t$-test was used to compare results between treatment and control groups. Bivariate correlation test was done to test the association between variables. $P<0.05$ was considered as significant, and $P<0.001$ was considered as highly significant.

\section{Results}

\section{This study included two groups}

- Treatment group included 20 thalassemic children (15 males and five females aged $9.07 \pm 4.26$ years) who received ICT plus Al-hijamah. The treatment group was evaluated twice: just before Al-hijamah (PIET) and 10 days after it (ICT+Al-hijamah).

- Control group included age-and sex-matched 20 thalassemic children who received ICT only.

\section{Al-hijamah improved transfusion dependence in thalassemia patients}

This pilot study was limited by the decreased number of patients and the relatively short duration of follow-up after Al-hijamah. Hemoglobin levels were assessed prior to Al-hijamah as an inclusion criterion. With regard to the requirement of thalassemic children to get repeated blood transfusions, Al-hijamah decreased that by $\sim 20 \%$ (data not shown). Thalassemic children who received a single session of Al-hijamah in addition to ICT exhibited less requirement for repeated blood transfusion compared to those who received ICT alone.

\section{Al-hijamah is a safe and tolerable hematological procedure}

Al-hijamah was a quite safe hematological procedure that was afforded by all the pediatric patients who participated in the study (Figures 1-3). No side effects were reported in any of the 20 patients. No fainting attacks or hemorrhage was reported. At the beginning, children were afraid and calmed by the parents and the friendly attitude of the pediatric hematologists. The first suction step caused the creation of skin upliftings that were characterized by transient hypothesia compared to the surrounding skin regions. This decreased to a large extent the expected pain during scarification of the skin of the upliftings. At the end of the procedure, children walked quietly and did not need to sleep or get rest. Interest- ingly, children themselves and their parents requested to do Al-hijamah once more in the near future. Al-hijamah was done to all patients according to the same schedule, ie, same number of cups was applied to all. Laboratory assessment was done on the tenth day after Al-hijamah.

\section{Al-hijamah is associated with a minimal bloody excretion}

We report here that the bloody excretion coming through Alhijamah was a minimal blood loss where the average amount of the bloody excretion was $\sim 50 \mathrm{cc}$, which did not aggravate the anemic status in thalassemic patients (Figure 3G).

\section{Al-hijamah significantly decreased iron overload}

Al-hijamah acted as an efficient PIET in all the investigated 20 thalassemic children whose serum ferritin was efficiently decreased (Figure 4A, Table S1). Serum malondialdehyde decreased markedly with Al-hijamah. TAC subsequently increased as a consequence of excretion of ROS (Table S1). Results of laboratory assessment revealed that mean serum ferritin before the procedure (Alhijamah) was $3,778.350 \pm 551.633 \mathrm{ng} / \mathrm{mL}$, which dropped to $2,825.300 \pm 558.94 \mathrm{ng} / \mathrm{mL}$ after the procedure with a highly significant difference $(P<0.001)$. For controls, serum ferritin was $3,787.40 \pm 123.81 \mathrm{ng} / \mathrm{mL}$ and remained high. No significant difference was reported upon using ICT only.

\section{Al-hijamah significantly reduced the high thalassemic oxidative stress}

Moreover, our data revealed that there was a significant negative correlation between serum malondialdehyde and T-helper CD4 cell count ( $r=-0.56, P=0.00)$ and also a significant negative correlation between serum malondialdehyde and serum serum glutamate pyruvate transaminase (Alt, alanine transaminase) that reflects liver function tests $(r=-0.38, P=0.01)$ (Figure 4B and C). There was also a significant negative correlation between serum ferritin and CD4 T-helper cell count $(r=-0.33, P<0.05)$, and no other significant negative correlation was found.

The mean value for serum malondialdehyde was $42.155 \pm 12.42 \mathrm{nmol} / \mathrm{L}$ before Al-hijamah and then dropped to $13.195 \pm 0.68 \mathrm{nmol} / \mathrm{L}$ after it $(P=0.03)$ and was $42.86 \pm 12.40 \mathrm{nmol} / \mathrm{L}$ for control subjects. The reverse was found forTAC, which increased from $0.2556 \pm .0 .0178 \mathrm{mmol} / \mathrm{L}$ before Al-hijamah to $0.667 \pm .0 .020 \mathrm{mmol} / \mathrm{L}$ after it $(P<0.001)$. For control subjects receiving ICT only, TAC was $0.2551 \pm 0.172 \mathrm{mmol} / \mathrm{L}$. 


\section{Therapeutic indices of Al-hijamah} Excretion index (EV)

$\mathrm{EV}=$ (initial concentration of any substance in serum before Al-hijamah in concentration unit/blood volume unit)-(concentration of the same substance in serum after Al-hijamah in concentration unit/blood volume unit).

$\mathrm{EV}$ for serum ferritin $=(3,778.35-2,825.3)=953.05 \mathrm{ng} /$ $\mathrm{mL}$, ie, upon treating thalassemic children with Al-hijamah, $\sim 953.05 \mathrm{ng}$ of ferritin was excreted from each milliliter of patient's blood.

EV for malondialdehyde $=42.155-13.195=28.96 \mathrm{nM} / \mathrm{L}$, ie, upon treating thalassemia with Al-hijamah, $28.96 \mathrm{nM} / \mathrm{L}$ of malondialdehyde was excreted from patient's blood.

\section{Purification index}

$\mathrm{PI}=100 \times$ ([initial concentration of any substance in serum before Al-hijamah-concentration of the same substance in serum after Al-hijamah]/initial concentration of same substance in serum before Al-hijamah).

PI for serum ferritin $=100 \times(3,778.35-2,825.3) /(3,778.35)$

$=100 \times 953.05 / 3,778.35$

$=25.22 \%$, ie, a single session of Al-hijamah decreased iron overload by $\sim 25.22 \%$.

PI for malondialdehyde $=100 \times(42.155-13.195) / 42.155$

$=100 \times 28.96 / 42.155$

$=68.69 \%$, ie, a single session of Al-hijamah decreased oxidative stress by $\sim 69 \%$.

\section{Pharmacological potentiation index}

PPI $=(100 \times$ therapeutic effects of [Al-hijamah+conventional pharmacological treatments]/[therapeutic effects of conventional pharmacological treatments only]).

PPI for raising the $\mathrm{TAC}=100 \times 0.667 / 0.2556$

$=260.95 \%$, ie, combination of Al-hijamah with ICT increases TAC in thalassemic children by $\sim 261 \%$.

All the patients in the control group did not undergo Alhijamah. No excretory benefit, clearance benefit or pharmacological potentiation was found in patients in the control group.

\section{Discussion}

Our objective was to develop new more effective treatment modalities to improve the therapeutic outcomes of current hematological conditions, eg, thalassemia and iron overload conditions. Al-hijamah is wet cupping therapy of prophetic medicine that we previously suggested as a promising iron reduction therapy based on Al-hijamah-induced excretory functions. ${ }^{9} 10$ Here, we proved our hypotheses and introduced Al-hijamah as a novel, safe and effective therapeutic modality for treating thalassemia. Excretory treatment modalities such as Al-hijamah and phlebotomy that remove excess harmful contents in blood and interstitial fluids, eg, ROS and excess ferritin, should receive more research attention as they reduce iron overload without causing a metabolic burden on the liver and kidneys. In this clinical trial, we confirmed that Al-hijamah was quite safe, tolerable and effective in treating thalassemic patients (Figures 1-3). Al-hijamah is an efficient PIET (through percutaneous iron excretion in the cupped bloody excretion) that significantly decreased serum ferritin in all the investigated thalassemic children (Figures 3 and 4 and Table S1). This can be explained on excretory bases where a significant portion of iron and ferritin was excreted in the cupped blood during the skin scarification step (superficial skin scarifications; the Arabic term is shartat mihjam) and the next suction step (pressure-dependent excretion; Figure 3). Al-hijamah exerted antioxidant benefits through increasing TAC (Figure 4C) and decreasing the serum levels of oxidant substances, eg, malondialdehyde (Figure 4B). Al-hijamah-induced excretion of oxidants may play a significant role in relieving the oxidative stress-induced harm during the course of thalassemia-induced tissue damage according to the evidence-based Taibah mechanism (Taibah theory). ${ }^{7,8}$ Interestingly, local skin clearance from iron using Al-hijamah may decrease iron deposition in the skin and clear it from iron-induced tissue damage. This may shift iron from blood to the cleared tissues (ie, redistribution) where more iron is cleared from blood to skin. By the next session of Al-hijamah, further clearance of blood iron and skin iron may occur, resulting in further decrease in iron overload. Consequently, decreasing iron overload through Al-hijamah may partially explain Al-hijamah-induced decrease in oxidative stress as iron is a major oxidant.

Nonproductive superficial skin scarifications (the Arabic term is shartat mihjam) and partially productive superficial skin scarifications (the Arabic term is shartat mihjam) may not achieve the efficient excretory function of Al-hijamah to give same therapeutic benefits as productive superficial skin scarifications (the Arabic term is shartat mihjam) (Figure 2C and D). Enhanced skin excretory functions during superficial skin scarifications (the Arabic term is shartat mihjam) seem to be the golden standard for the curative effects of Al-hijamah in agreement with the evidence-based Taibah mechanism (Taibah theory) ${ }^{7,8}$ Repeatability of Al-hijamah may increase its therapeutic benefits in chelating iron and reducing oxidative stress. There is no fixed specific day or a specific time of the day for performing Al-hijamah. However, in prophetic medicine, Alhijamah is recommended to be done in the days of the third quarter of the lunar month, particularly on days 17th, 19th and 21 st to protect against hypertension complications. Recently, Chakraborty and Ghosh reported that in the third quarter of the 
A

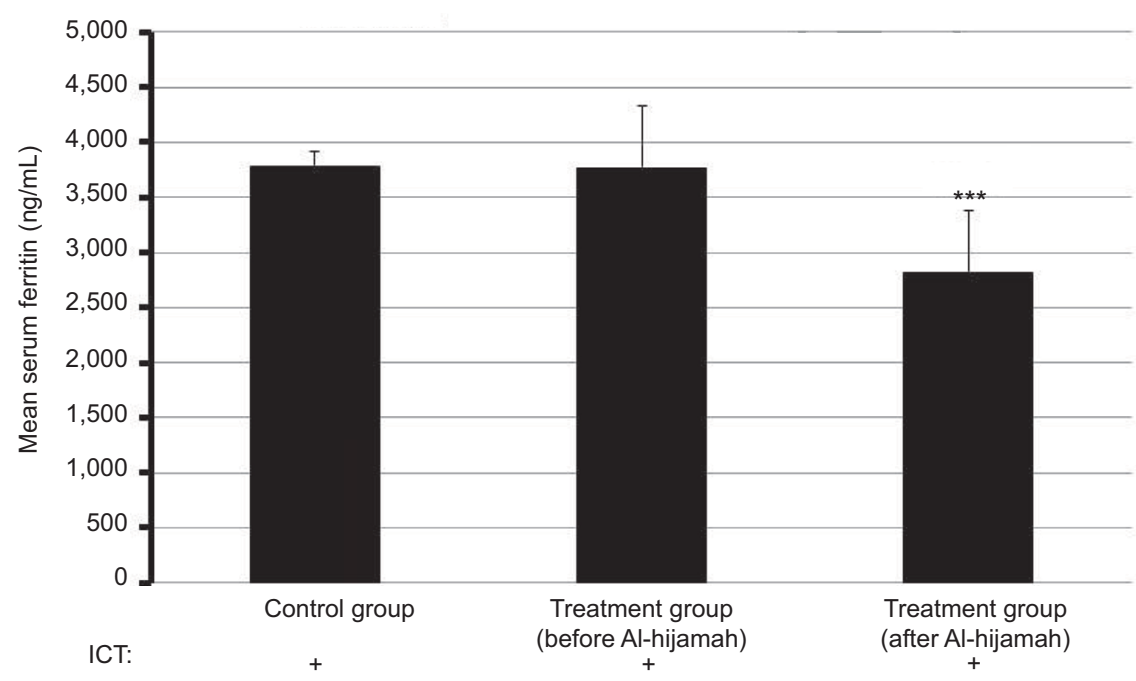

B

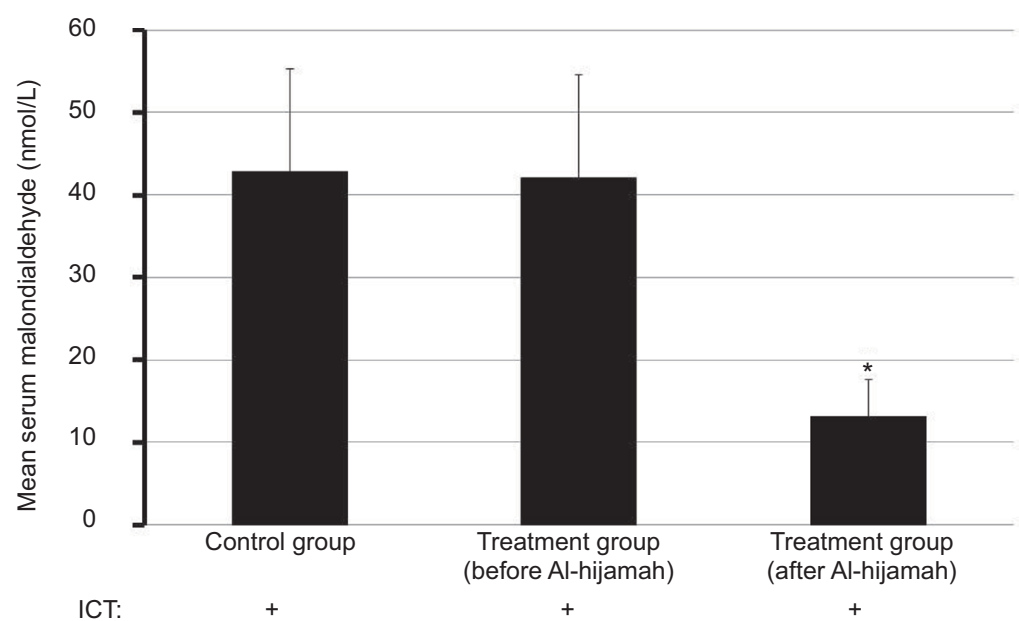

c

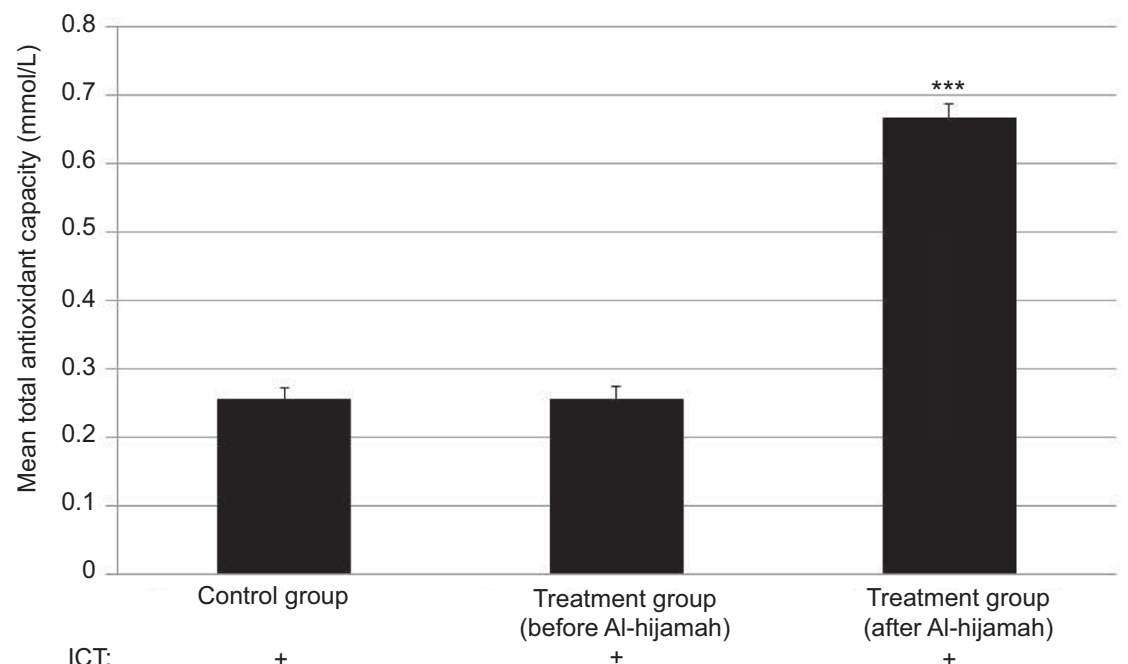

Figure 4 ICT plus Al-hijamah (wet cupping therapy of prophetic medicine) significantly decreased both serum ferritin and free radicals and improved the antioxidant power. Notes: All studied children are thalassemic children receiving ICT. The control group did not undergo Al-hijamah treatment. There is no healthy control. (A) ICT plus Al-hijamah significantly decreased serum ferritin $(* * * P<0.00 I)$. (B) ICT plus Al-hijamah significantly decreased serum malondialdehyde $(P<0.05)$. (C) ICT plus Al-hijamah significantly improved TAC $(* * * P<0.001)$.

Abbreviations: ICT, iron chelation therapy; TAC, total antioxidant capacity. 
lunar month, both systolic and mean arterial BP were higher with a decreased physical fitness index. The authors attributed that to the gravitational pull of the moon, which may affect the cardiovascular functions of the human body. ${ }^{15}$

Significance of our study is in its novelty in introducing a safe effective and cheap line of treatment for thalassemia (particularly in pediatric practice) that can be generalized to include other conditions of ICT. Our study proved safety of Al-hijamah in pediatric medical practice as a novel PIET to thalassemic children that significantly reduces iron overload, potentiates ICT and decreases oxidative stress. Medical practice of Al-hijamah in hospitals is strongly recommended as it is safe, time-saving, cost-effective and has many therapeutic benefits. This article teaches also medical practice of Al-hijamah.

\section{Conclusion}

Al-hijamah is a safe, economic, therapeutically effective hematological procedure that can be used in pediatric practice. Al-hijamah-induced blood loss is negligible. Al-hijamah is a wet cupping therapy of prophetic medicine, and prophet Muhammad, peace be upon him, strongly recommended Alhijamah, saying: "The best of your treatment is Al-hijamah". Al-hijamah may be more promising than phlebotomy in treating thalassemia and iron overload. Al-hijamah is a novel, safe, effective, promising iron-reducing therapy. Increasing the number of cups during Al-hijamah session or increasing the number of sessions may induce stronger excretion of iron and ferritin with a subsequent stronger reduction in iron overload. Al-hijamah is promising in pediatric medical practice. During Al-hijamah, skin acts as a super kidney causing general direct excretion of causative pathological substances in a physiological manner. Al-hijamah is a general clearance treatment that significantly and simultaneously clears tissues, intercellular fluids and blood of different pathological substances. Al-hijamah is strongly recommended to be practiced officially in hospitals as a respected prestigious therapeutic hematological procedure in modern medical practice.

\section{Future perspectives}

In light of the promising Al-hijamah-induced reduction in both iron overload and oxidative stress and the promising increase in TAC gained in this study, we plan to do a large-scale future study with a prolonged follow-up over a longer period of time.

\section{Acknowledgments}

The authors are so grateful for lovely Mohamed Salah for his support in the video abstract. The authors are also so grateful to the excellent computer engineer $\mathrm{Mr}$ Ahmed Mohamed El Sayed for his kind support in performing the video abstract. No funding was received. The article is supported by the authors. The authors are so grateful to Taibah University, Saudi Arabia for allowing a helpful environment to conduct this study. The authors are very grateful to $\mathrm{Mr}$ Adel Obaidi, Mr Raed Ali Al-Raddadi, Mr Sultan Al-Hussini, Mr Mohamed Abdelsamad, and Mr Wael Barakat from the Administrative Department, College of Medicine, Taibah University for their technical help and support in this work.

\section{Disclosure}

The authors report no conflicts of interest in this work.

\section{References}

1. Ozturk Z, Genc GE, Gumuslu S. Minerals in thalassaemia major patients: An overview. J Trace Elem Med Biol. 2017;41:1-9.

2. Gursel O, Kurekci AE, Tascilar E, et al. Premature atherosclerosis in children with $\beta$-thalassemia major. J Pediatr Hematol Oncol. 2012;34(8): 630-634.

3. Roussou P, Tsagarakis NJ, Kountouras D, Livadas S, Diamanti-Kandarakis E. Beta-thalassemia major and female fertility: the role of iron and iron-induced Anemia. 2013;2013:617204.

4. Adly AAM, Elsherif NHK, Ismail EAR, Ibrahim YA, Niazi G, Elmetwally $\mathrm{SH}$. Ischemia-modified albumin as a marker of vascular dysfunction and subclinical atherosclerosis in $\beta$-thalassemia major. Redox Rep. 2017;22(6):430-438.

5. Unchern S, Laoharuangpanya N, Phumala N, et al. The effects of vitamin E on platelet activity in beta-thalassaemia patients. Br J Haematol. 2003;123(4):738-744.

6. Michalsen A, Bock S, Lüdtke R, et al. Effects of traditional cupping therapy in patients with carpal tunnel syndrome: a randomized controlled trial. J Pain. 2009;10(6):601-608.

7. El Sayed SM, Mahmoud HS, Nabo MMH. Medical and scientific bases of Wet Cupping Therapy (Al-Hijamah): In Light of Modern Medicine and Prophetic Medicine. AlternInteg Med. 2013;2:1-16.

8. El Sayed SM, Al-Quliti A-S, Salah Mahmoud H, El Sayed SM, Mahmoud HS, et al. Therapeutic Benefits of Al-hijamah: in Light of Modern Medicine and Prophetic Medicine. American Journal of Medical and Biological Research. 2014;2(2):46-71.

9. El Sayed SM, Baghdadi H, Abou-Taleb A, et al. Al-hijamah and oral honey for treating thalassemia, conditions of iron overload, and hyperferremia: toward improving the therapeutic outcomes. J Blood Med. 2014;5:219-237.

10. El Sayed SM, Abou-Taleb A, Mahmoud HS, et al. Percutaneous excretion of iron and ferritin (through Al-hijamah) as a novel treatment for iron overload in beta-thalassemia major, hemochromatosis and sideroblastic anemia. Med Hypotheses. 2014;83(2):238-246.

11. Baghdadi H, Abdel-Aziz N, Ahmed NS, et al. Ameliorating Role Exerted by Al-Hijamah in Autoimmune Diseases: Effect on Serum Autoantibodies and Inflammatory Mediators. Int $J$ Health Sci. 2015;9(2):203-227.

12. Ahmadi A, Schwebel DC, Rezaei M. The efficacy of wet-cupping in the treatment of tension and migraine headache. Am J Chin Med. 2008;36(1):37-44.

13. Cazzola M, de Stefano P, Ponchio L, et al. Relationship between transfusion regimen and suppression of erythropoiesis in beta-thalassaemia major. Br J Haematol. 1995;89(3):473-478.

14. Cazzola M, Borgna-Pignatti C, Locatelli F, Ponchio L, Beguin Y, de Stefano P. A moderate transfusion regimen may reduce iron loading in beta-thalassemia major without producing excessive expansion of erythropoiesis. Transfusion. 1997;37(2):135-140.

15. Chakraborty U, Ghosh T. A study on the physical fitness index, heart rate and blood pressure in different phases of lunar month on male human subjects. Int J Biometeorol. 2013;57(5):769-774. 


\section{Supplementary material}

Table SI Effect of Al-hijamah (wet cupping therapy of prophetic medicine) as an effective PIET in reducing iron overload and oxidative stress with subsequent increase in TAC

\begin{tabular}{|c|c|c|c|c|c|c|}
\hline \multirow[t]{2}{*}{ Patient no } & \multicolumn{2}{|c|}{ Serum ferritin (ng/mL) } & \multicolumn{2}{|c|}{ Serum malondialdehyde (nM/L) } & \multicolumn{2}{|c|}{ Mean TAC (mM/L) } \\
\hline & $\begin{array}{l}\text { Before } \\
\text { Al-hijamah }\end{array}$ & $\begin{array}{l}\text { After } \\
\text { Al-hijamah }\end{array}$ & $\begin{array}{l}\text { Before } \\
\text { Al-hijamah }\end{array}$ & $\begin{array}{l}\text { After } \\
\text { Al-hijamah }\end{array}$ & $\begin{array}{l}\text { Before } \\
\text { Al-hijamah }\end{array}$ & $\begin{array}{l}\text { After } \\
\text { Al-hijamah }\end{array}$ \\
\hline $\mathrm{I}$ & 2,864 & I,426 & 29.5 & 14 & 0.23 & 0.59 \\
\hline 2 & 1,407 & 1,005 & 30.9 & 19.1 & 0.4 & 0.67 \\
\hline 3 & 1,000 & 977 & 25.5 & 12.2 & 0.35 & 0.55 \\
\hline 4 & 3,215 & 2,712 & 27.9 & 13.9 & 0.32 & 0.72 \\
\hline 5 & 2,105 & 1,900 & 22.2 & 7 & 0.15 & 0.51 \\
\hline 6 & 7,251 & 6,120 & 28.5 & 14.2 & 0.29 & 0.72 \\
\hline 7 & 2,799 & 2,182 & 50.1 & 19.6 & 0.27 & 0.6 \\
\hline 8 & 9,210 & 8,530 & 32.2 & 15 & 0.23 & 0.59 \\
\hline 9 & 2,210 & $\mathrm{I}, 148$ & 30.1 & 14.9 & 0.39 & 0.7 \\
\hline 10 & 3,316 & 1,990 & 29.5 & 7.4 & 0.28 & 0.63 \\
\hline II & 4,200 & 400 & 22.5 & 7.6 & 0.14 & 0.61 \\
\hline 12 & 2,325 & 1,870 & 32.5 & 19.9 & 0.28 & 0.56 \\
\hline 13 & 3,400 & $2,24 I$ & 277 & 12.5 & 0.14 & 0.73 \\
\hline 14 & 7,527 & 6,692 & 29.3 & 13.5 & 0.28 & 0.58 \\
\hline 15 & 1,988 & 1,065 & 30.9 & 11.3 & 0.15 & 0.83 \\
\hline 16 & 3,215 & 2,398 & 26.8 & 14.8 & 0.22 & 0.77 \\
\hline 17 & 2,799 & 2,182 & 32.2 & 15.1 & 0.15 & 0.8 \\
\hline 18 & 9,210 & 8,530 & 27.9 & 7.9 & 0.31 & 0.69 \\
\hline 19 & 2,210 & $\mathrm{I}, \mathrm{I} 48$ & 25.6 & 10 & 0.26 & 0.8 \\
\hline 20 & 3,316 & 1,990 & 32 & 14 & 0.27 & 0.69 \\
\hline Mean & $3,778.35$ & $2,825.3$ & 42.155 & 13.195 & 0.2555 & 0.667 \\
\hline SD & $2,466.986853$ & $2,499.65789$ & 55.56347224 & 3.85725222 & 0.07983370 & $0.0925 \mid 45$ \\
\hline SEM & 551.8986249 & 559.207582 & 12.43030699 & 0.86291996 & 0.01785989 & 0.0206967 \\
\hline
\end{tabular}

Abbreviations: PIET, percutaneous iron excretion therapy; TAC, total antioxidant capacity; SEM, standard error of mean.

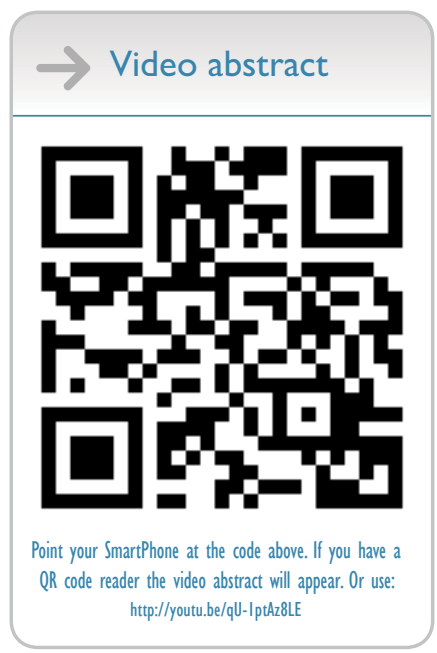

Journal of Blood Medicine

\section{Publish your work in this journal}

The Journal of Blood Medicine is an international, peer-reviewed, open access, online journal publishing laboratory, experimental and clinical aspects of all aspect pertaining to blood based medicine including but not limited to: Transfusion Medicine; Blood collection, Donor issues, Transmittable diseases, and Blood banking logistics; Immunohematology; Artificial and alternative
Dovepress

blood based therapeutics; Hematology; Biotechnology/nanotechnology of blood related medicine; Legal aspects of blood medicine; Historical perspectives. The manuscript management system is completely online and includes a very quick and fair peer-review system. Visit http://www.dovepress.com/ testimonials.php to read real quotes from published authors. 